Seleznova Olha,

Doctor of Sciences (Law), Associate Professor, Chernivtsi Institute of Trade and Economic of Kyiv National University of Trade and Economic, 7 Tsentralna Square 7, Chernivtsi, 58002, Ukraine ORCID: 0000-0001-5095-277X

Researcher ID: V-6649-2019

\title{
INFORMATION RIGHTS AND WAYS OF LEGAL FIXING THEM IN UKRAINE
}

Having found out that the current conditions of development of the information society have led to the presence and further transformation of a large number of information rights, the article argues for the need for adequate legal regulation of such rights. Analyzing the state of normative regulation of information rights in the world, the study proposes possible ways of normative consolidation of information rights in Ukraine, namely: to implement the current international norms in national legislation, to consolidate the legal acts regulating information relations in Ukraine, to promote information relations in Ukraine.

Keywords. Information rights, information legislation, implementation, consolidation, codification.

Селезньова Ольга. Інформаційні права та способи ӥх правового закріплення в Украӥні.

3'ясувавщи, що сучасні умови розвитку інформачійного суспільства спричинили наявність та подальщу трансформацію великої кількості інформачійних прав, у статті аргументується потреба в адекватному нормативно-правовому регулюванні таких прав. Проаналізувавщи стан нормативної регламентації інформаційних прав в світі, у дослідженні пропонуються можливі шляхи нормативного закріплення інформаційних прав в Украӥні, а саме: провести імплементацію діючих міжнародних норм у вітчизняне законодавство, здійснити консолідацію нормативно-правових актів, що регламентують інформаційні відносини в Україні, сприяти проведенню кодифікації.

Ключові слова. Інформачійні права, інформачійне законодавство, імплементаиія, консолідачія, кодифікація.

Relevance of the research topic. Scientific advances in medicine, computer science, robotics, etc., give factual reasons for scientists to identify the fourth generation rights system. Such new rights, both of individuals and of humanity as a whole, arise in connection with the rapid and continuous development of modern 
society, and above all, its informational component. The position of having such a fourth generation of human rights and the structure of the complex of such rights (with a positive resolution of the first aspect) are debatable. Questions also arise as to the attribution of the set of information rights to the rights of the fourth generation, which information rights are included in the said population, and also whether they independently form the system of rights of the fourth generation, or together with somatic rights (right to donation, right to artificial insemination, right to cadaveric transplant and others). To solve these tasks is of the utmost importance and urgency today, as the information society is formed at an unpredictably fast pace, and each of the emerging rights needs to be enshrined in its legal and regulatory framework.

Formulation of the problem. Information rights can be understood as stateguaranteed opportunities for a person to satisfy his or her aspirations and requirements in the direct or indirect receipt, use, distribution and protection of a certain range of information. Taking into consideration the working hypothesis, the position that these information rights are included in the fourth generation rights system raises the problem of establishing both the information rights system itself and variants of their possible regulatory regulation.

Analysis of recent research and publications. Among the scholars who dealt with the problems of information rights in Ukraine, one should mention Bryzhko V. (Bryzhko, 2009), Kalyuzhnyj R. (Kalyuzhnyj, 2013), Kopan O., Marcenyuk O., Sukhorolskyj P. (Sukhorol's'kyj, 2013) and others. At the international level, some aspects of the problem were raised in the works of Knox J. (Knox, 2008), Jorgensen R. (Jorgensen, 2006).) and others. Appreciating their unconditionally great contribution to the science of information law, it is also necessary to point out that the issues of the information rights system and the possibilities of their legal regulation remain open and need to be addressed.

Presenting main material. The steady development of the information society has led to the emergence and further transformation of a number of rights, which we call information. Such rights form their system, which we propose to portray as follows (Seleznova, Knox, 2014):

Depending on the level of legal regulation, information rights are divided into: 1) those enshrined in international legal acts; 2) such as are enshrined in the legislation of Ukraine. The second group of information rights can be differentiated by two criteria:

- according to the criterion of the type of legal and legal source in which they get their legal regulation information rights: a) constitutional information rights enshrined in the Constitution of Ukraine (right to free information gathering; right to free storage of information; right to free use and dissemination of information; right to free access to environmental information, right to be informed in state authorities, local self-government bodies, institutions and organizations about themselves that are not state or other protected law; secrecy; the right to freedom of thought and expression; the right to judicial protection of information rights; b) supplementary information rights - enshrined in laws and by-laws (legal regulation of such rights as 
the right to freedom of press, right to information space, free from materials that threaten the physical, intellectual, moral and psychological state of the population, right to know persons during the period of gathering information, but before using it, what information about it and for what purpose is collected, how, by whom and for what purpose it is used, transmitted or disseminated, the right of the person to access information and about her, which is collected and stored, and other rights, we find in the laws of Ukraine «On the print media (press) in Ukraine», «On the protection of public morals», «On access to public information», «On scientific and technical information», Etc.).

- according to the criterion of the extent to which the subjects of a legal relationship are: 1) fundamental information rights: a) the right to information - the primary and the core of all information rights; $b$ ) establishing fundamental rights (right of access to information; right of acquaintance in state bodies, local self-governments, institutions and organizations with information about themselves, which is not a state or other protected by law secret; right to freedom of thought and speech; right to freedom of the press; the right to an information space free from materials that threaten the physical, intellectual, moral and psychological state of the population); c) court fundamental rights (the right to refute false information about oneself and their family members in court; the right to request the removal of any information; the right to compensation for material and non-pecuniary damage caused by the collection, storage, use and dissemination of false information); 2) specific information rights (the right to information about their health status; the right to secrecy about their health status; the right to personal papers; the right to see personal papers transferred to the library or archives fund; the client's right to access information on the activity of the bank; the client's right to bank secrecy; the right of the bank to provide general information that constitutes banking secrecy to other banks to the extent required when granting loans, bank guarantees; the right of trade unions, their associations, to receive free of charge and information from employers or their associations on matters relating to labor and socio-economic rights and the legitimate interests of their members, as well as information on the economic performance of enterprises, institutions or organizations, and other rights).

Such a broad classification of information rights requires its proper legal formulation.

It should be noted that in the world information legislation is developing quite intensively. It is worth noting the fact that basic information rights are found at the constitutional level. In particular, the right to freely collect information is enshrined in Article 34 of the Constitution of the Republic of Moldova, Article 20 of the Constitution of the Kingdom of Spain, Article 50 of the Constitution of the Republic of Azerbaijan; the right to free storage of information - in Article 34 of the Constitution of the Republic of Belarus; the right to free use and dissemination of information - in Article 34 of the Constitution of the Republic of Belarus, Article 20 of the Constitution of the Kingdom of Spain, Article 50 of the Constitution of the Republic of Azerbaijan; the right of free access to information on the state of the 
environment - in Article 37 of the Constitution of the Republic of Moldova, Article 34 of the Constitution of the Republic of Belarus, Article 74 of the Constitution of the Republic of Poland, Article 39 of the Constitution of the Republic of Azerbaijan; the right to familiarize themselves with state information, bodies of local self-government, institutions and organizations with information about themselves that is not a state or other lawfully protected secret - in Article 25 of the Constitution of the Republic of Lithuania, Article 51 of the Constitution of the Republic of Poland; the right to freedom of thought and expression - in Article 32 of the Constitution of the Republic of Moldova, Article 37 of the Constitution of the Portuguese Republic, Article 47 of the Constitution of the Republic of Azerbaijan and others. In Ukraine, these rights are also enshrined in the Constitution of Ukraine, namely Articles 32, 34, 50, which is a positive achievement of the legislator.

In addition to the rights enshrined in the constitutions of states, there are a number of rights that reach their legal regulation through law. For example, in the United States of America, the laws governing Freedom of Information Act, Telecommunications Act, About Free National Internet Access, and About Confidential Information; in France - «About Access to Information», «About the Press»; in Germany - «Information and Communication Services», «Regulating Access to Information»; in the UK - «About freedom of information», in Belarus «About information, informatization and information security». Ukraine also has a number of laws that, as noted above, regulate supplementary information rights.

It should also be noted that at the same time, international legal acts are in force, which also regulate a certain amount of information rights (for example, the Declaration on the Freedom of Expression and Information (1982), the Directive of the European Parliament and of the Council concerning the processing of personal data and the protection of privacy in the telecommunications sector (1997), Council of Europe Recommendation on Access to Official Documents (2002) and many others.

From the above it follows that, both in the world and in Ukraine, there is a certain set of legal acts that regulate information rights. However, as already noted, this is clearly not enough in view of the rapid and continuous development of the information society and the emergence of new (transformation of existing) information rights.

Summarizing the above situation, we can propose the following ways of possible regulatory registration of information rights.

First, to implement the current international norms in domestic legislation. In other words, to stimulate the transformation of the norms of international law into the rules of domestic law, while choosing a specific way - transformation, reception or sending. Such a path should be taken into account, because it can be used to comply with existing and new international standards of regulation of information rights, to provide global strategies for development of the world information society within the country, to support the general international tendencies of normative regulation of modern ideas for further regulation of information rights. 
Second, to consolidate the legal acts regulating information relations in Ukraine. That is, to create a consolidated act by combining and externally processing the information rules governing information rights. If such an act were to take place, it would become a source of information law, which would provide for the regulation of one of the institutions of this branch of law - the information rights institute.

Third, to facilitate codification, namely: to develop and adopt the Information Code of Ukraine - a codification source of information law of Ukraine, in which structure, in addition to the section (chapters) on information rights, there will be sections (chapters) containing norms that regulate and other information law institutes.

Conclusion. Information rights are one of the most important institutions in the system of information law. The theoretical substantiation of information rights is at an early stage, but the possibility of exercising such rights is not only a manifestation of the discovery of democracy in a particular country, but must also become one of the leading segments of the states information policy. That is why full and adequate regulation of information rights today should become one of the priority tasks of the Ukrainian Parliament. And in order to best solve this problem, the legislator needs to take a comprehensive approach to solving it, while applying the methods of implementation, consolidation and codification of the rules that regulate and regulate information rights in Ukraine.

\section{REFERENCES}

1. Bryzhko, V. M. (2009). Metodologichni ta pravovi zasady uporyadkuvannya informacijnykh vidnosyn [Methodological and legal principles of ordering information relations]. Kyiv, Ukrayina, 2009. 304 p. [in Ukrainian].

2. Kalyuzhnyj, R. A., Kopan, O. V. \& Marcenyuk, O. G. (2013). Teoretykometodologichni zasady informacijnogo prava Ukrayiny: realizaciya prava na informaciyu [Theoretical and methodological principles of information law of Ukraine: realization of the right to information]. Kyiv, Ukrayina, 2013. $236 \mathrm{p}$. [in Ukrainian].

3. Sukhorol's'kyj P. M. (2013). Problemy zabezpechennya ta rozvytku prav lyudyny $\mathrm{v}$ umovakh informacijnogo suspil'stva [Problems of ensuring and development of human rights in the conditions of information society]. Ukrayins 'kyj chasopys mizhnarodnogo prava. Ukrainian Journal of International Law. № 1. P. 18-23.

4. Knox, J. (2008). Horizontal Human Rights Law. The American Journal of International Law. Vol. 102. № 1. P. 1-47.

5. Jorgensen, R. F. (2006). Human Rights in the Global Information Society. The Massachusetts Institute of Technology. 2006. $325 \mathrm{p}$.

6. Seleznova, O. M., Knox, J. (2014). Teoretyko-metodolohichni osnovy informatsiynogo prava Ukrayiny [Theoretical and methodological foundations of information law of Ukraine]. Chernivtsi, Ukrayina, 2014. 408 p. [in Ukrainian]. 